\title{
Magas Bianka ${ }^{1 \odot}$ \\ A megfigyelés és a kínai típusú szociális kreditrendszer társadalmi megítélése
}

\author{
The Social Judgment of Surveillance \\ and the Chinese-type Social Credit System
}

A mesterséges intelligencia egyre nagyobb teret nyer magának mindennapjainkban, az általunk használt eszközök, szolgáltatások révén megkerülhetetlen részét képezi életünknek. Számtalan felhasználási területe közül a lakosság állami, vállalati megfigyelését egyre nagyobb érdeklődés övezi. Az állampolgárokról hatalmas mennyiségben gyüjtött adatok mesterséges intelligenciával való feldolgozása, kiértékelése számos ajtót megnyit az azokat birtokló vállalatoknak, államoknak. Kérdés azonban az, hogy vajon a társadalom is akar a megfigyelés társadalmává válni? Kínában már kiépülöben van egy, a lakosokat 24 órás megfigyelés alatt tartó rendszer, amely pontozza, pontjaik szerint pedig jutalmazza vagy bünteti az állampolgárokat. Vajon lehetséges egy szociális kreditrendszer Nyugaton is? Támogatnák-e az emberek a privát szférájuk szükülését a szolgáltatásukért és biztonságukért cserébe? Írásunk egy kérdőíves felmérés segítségével meghatározza, a technológiaelfogadás-modellt alapul véve, hogy mekkora támogatottságot élvezne a széles körü digitális állami megfigyelés, milyen tényezők befolyásolhatják ennek a megítélését. A kérdőives felmérés részét képezi a vállalati megfigyeléshez való lakossági viszonyulás is, ahol a dolog támogatottságát, a támogatottságot befolyásolható tényezőket vizsgálja.

Kulcsszavak: mesterséges intelligencia, megfigyelés, big data, kínai szocális kreditrendszer

The role of artificial intelligence in our everyday life has been growing since its presence in our gadgets and the services that we use. The plenty of areas in which Al has used the interest in applying it for the surveillance of the people has been intensifying. The huge amount of data collected from the citizens and processed by artificial 
intelligence opens numerous doors for companies and states. The question arises whether society really wants to become a surveillance society. In China, a system will be introduced nationwide which is based on the constant surveillance of the citizens. According to their behaviour, they receive credits, based on their credit they get reward or punishment. Would it be possible to introduce a system like this in western society? Would the people support it for the benefits and their security even if they must give up their private sphere? With an online survey, the author defines the support of people for an extensive digital state surveillance system and what factors influence opinions. The survey also includes the opinion of the people about the surveillance done by tech companies and the factors that affect them. With this research, we get an inside view of the people's acceptance of surveillance.

Keywords: artificial intelligence, surveillance, big data, Chinese social credit system

\section{Bevezetés}

A mesterséges intelligencia ${ }^{2}$ egyre nagyobb teret nyer magának mindennapjainkban, az általunk használt eszközök, szolgáltatások révén megkerülhetetlen részét képezi életünknek. Számtalan felhasználási területe közül a lakosság állami, vállalati megfigyelését egyre nagyobb érdeklődés övezi. Az állampolgárokról hatalmas mennyiségben gyüjtött adatok mesterséges intelligenciával való feldolgozása, kiértékelése számos ajtót megnyit az azokat birtokló vállalatoknak, államoknak. Felhasználási módját tekintve pedig nagyon fontos, hogy a témát minél szélesebb körben feszegessük, mert egyre közelebb kerül a mindennapjainkhoz.

Arra, hogy egy szuperhatalom hogyan használja tömeges magatartásbefolyásolásra, már napjainkban is látunk példát. Kínában egy, az állampolgárokat 24 órás megfigyelés alatt tartó, szociális kreditrendszer kiépítését szorgalmazta a párt az elmúlt években, országos szintü kiterjesztéséről 2014-ben döntöttek. Alapját a mesterséges intelligencia és a big data ${ }^{3}$ szolgáltatja. Lényege a lakosság folyamatos megfigyelése és értékelése, majd az értékelésen alapuló jutalmazás vagy büntetés. A lehető legkülönbözőbb forrásokból gyűjtenek hatalmas mennyiségü adatot az állampolgárokról, úgymint a tevékenységükből a közösségi médián, böngészési előzményekből, pénzügyi előzményekből, vásárlási szokásokból. A nagy mennyiségü adat feldolgozását és kiértékelését pedig mesterséges intelligencia végzi. ${ }^{4}$

\footnotetext{
Peter Jackson megfogalmazása szerint „A mesterséges intelligencia a számítógéptudomány azon részterülete, amely az ember olyan kognitív (megismerő) képességeit emuláló számítógépi programok tervezésével és alkalmazásával foglalkozik, mint a problémamegoldás, vizuális érzékelés és a természetes nyelvek megértése." A mesterséges intelligenciát értelmezhetjük emberi módon gondolkodó rendszereknek, emberi módon cselekvő rendszereknek, racionálisan gondolkodó rendszereknek és racionálisan cselekvő rendszereknek. Forrás: MihályDeák Tamás: A mesterséges intelligencia alapjai. Előadás. 2018. február 3.

3 A Big data „olyan adatbázist ír le, amelyet gyakran frissített adatok (sebesség) hatalmas mennyisége (terjedelem) jellemez, s ezen adatok különféle formátumban lelhetök fel, úgymint numerikusan, szövegesen, kép/ videó formában (változatosság)." Andreas Kaplan - Michael Haenlein: Siri, Siri, in My Hand: Who's the Fairest in the Land? On the Interpretations, Illustrations, and Implications of Artificial Intelligence. Business Horizons, 62. (2019), 1. 15-25.

4 Genia Kostka - Lukas Antonie: China's Social Credit Systems and Public Opinion: Explaining High Levels of Approval. Policy Studies Organization, 21. (2019), 7. 1565-1593.
} 
Az állampolgárok folyamatos felügyeletét lehetővé teszik az utcákon, üzletekben kihelyezett okos CCTV-kamerák. 2018-ban 394 millió térfigyelő kamera volt kihelyezve, azonban ezek száma folyamatosan növekszik, különösen a koronavírus-járvány következtében. 2021-re Kínában összesen akár 567 millió térfigyelö kamera is lehet egyes becslések szerint. ${ }^{5}$ Célja, hogy megbízhatóságra és törvénytiszteletre ösztönözze az állampolgárokat, vállalatokat, szervezeteket és állami szerveket. A népi kormányok feketelistát tesznek közzé, amelyen a megbízhatatlannak bélyegzett vagy illegális magatartást tanúsító személyek szerepelnek, akik további szankciókat is kapnak viselkedésükért (például nagysebességü vonatjegy-vásárlás ellehetetlenítése). Ugyanakkor a megbízhatónak minősített személyek és szervezetek számára új listát tesznek közzé, illetve azok jutalomban részesülnek (például adócsökkentés, könnyebb hozzáférés állami szolgáltatásokhoz).

Az állampolgárok mesterséges intelligenciával történő megfigyelésének és akár pontozásának gondolata pedig nem korlátozódik csupán az említett országra, a nyugati világban is szárnyukat bontogatják az államok, óriásvállalatok (például a Google, Facebook) által. ${ }^{6} \mathrm{~A}$ felhasználók folyamatos megfigyelésének egyik célja a vállalatok részéről föként a profitszerzés. Olyan algoritmus kialakítására törekszenek például a közösségi oldalak, amelyek szokásainkat elemezve próbálják kitalálni, mi az a tartalom, ami érdekelhet minket. Figyelik, hogy milyen témákban olvasunk, milyen oldalakat látogatunk, eszerint szelektálva jutunk hírekhez, hirdetésekhez. Így, ha a felhasználó például elkötelezett egy párt vagy ideológia iránt, jó eséllyel egy idő után csak ilyen tartalmakkal találkozik, az ellenvéleménnyel aligha. Ezzel lehetőség nyílik a felhasználók befolyásolására. ${ }^{7} \mathrm{~A}$ mesterséges intelligencia által támogatott megfigyelésen túl találkozhatunk a kreditrendszer bizonyos formáival is. Az Airbnb algoritmusa pedig a „gyanús” profilokat képes kiszűrni. Ugyanúgy az Instagramnak is van ilyen szürője, amely Kaylen Ward kapcsán vált híressé, aki az ausztráliai bozóttűz áldozatainak szervezett gyűjtést Twitter-fiókján keresztül úgy, hogy meztelen képeket ajánlott fel azoknak, akik bizonyítottan adakoztak az ausztrál vöröskeresztnek vagy a koalakórházaknak. S bár az Instagramját nem használta gyüjtésre, mégis le lett tiltva a profilja, mert viselkedésével megsértette az Instagram szexuálisan szuggesztív tartalomra vonatkozó irányelveit. ${ }^{8}$ Van egy terület az Egyesült Államokban, ahol a vállalati megfigyelés és a kreditrendszer találkozik: a bankszektor. Hitelfelvételnél müködik egy kreditrendszer, amely az állampolgárt egy 300-tól 850-ig terjedő skálán pontozza, meghatározva ezzel milyen valószínüséggel tudja visszafizetni a hitelét. ${ }^{9}$ Ezt a kreditpontot pedig a közösségi médián posztoltak is befolyásolhatják. ${ }^{10}$

\footnotetext{
Nectar Gan: China is Installing Surveillance Cameras Outside People's Front Doors ... And Sometimes Inside Their Homes. CNN Business, 2020. április 28.

Shoshana Zuboff: The Age of Surveillance Capitalism. London, Profile Books Ltd., 2019.

Bányász Péter: A közösségi média szerepe a lélektani műveletekben az elmúlt időszak válságainak tükrében. Szakmai Szemle, 13. (2016), 1. 61-81.

8 Herczeg Márk: Eljött az idő, amikor az online tevékenységed alapján pontozzák, mennyire vagy megbízható állampolgár. 444, 2020. január 27.

Joe Resendiz: Average Credit Score in America: 2021 Report. Valuepengiun, 2019. július 9.

10 Craig Johnson: The truth about how Facebook can affect your credit score. Clark, 2017. december 17.
} 
Az Amerikai Egyesült Államokat tekintve a nagy techóriások, közösségimédia-felületek által végzett megfigyelése pedig összeér az állami megfigyeléssel valahol a nemzetbiztonság területén. Erre szolgált például az Edward Snowden által megszellőztetett precedens is, ahol a National Security Agency ${ }^{11} 3$ milliárd telefonhívást hallgatott le, illetve fért hozzá a Google, Facebook, Apple és más techcégek által szolgáltatott rögzített adatokhoz. ${ }^{12}$ Nem elképzelhetetlen annak a gondolata, hogy a megfelelő technológiával rendelkezó államok is használatba veszik a nagy techóriások által kínált technológiát, ahogy erre egyre több példát látunk. ${ }^{13}$ Továbbá egyre több vállalkozás, kormány használja a felhasználók online tevékenységét annak eldöntésére, hogy a lakosok, illetve ügyfelek megbízhatóak-e.

Különösen aktuálisnak érzem a témát, hisz rengeteg jogi, társadalmi, gazdasági, filozófiai kérdést felvet, kezdve az emberi jogi kérdésektől, a túlzott állami hatalom kiépítésén át a tömeges magatartásbefolyásolás etikai oldaláig. Azért is érdemes ezzel többet foglalkozni, mert a terület robbanásszerü fejlődését nem követik megfelelő mértékü emberi jogi intézkedések. A felhasználók, állampolgárok zöme nincs tudatában a vállalatok általi megfigyelésnek, a már működő rendszereknek, nem érti, milyen veszélyeket rejthet. Azonban már megoszló nézeteket vallanának, ha tudnák, hogy az állam vagy magáncégek mekkora befolyást és hatalmat szereznek az önként átadott személyes adataik révén az életük felett.

\section{Módszertan}

Vajon a társadalom is akar a megfigyelés társadalmává ${ }^{14}$ válni? Kutatásom célja, hogy felmérjem az állami, vállalati megfigyelés lakossági támogatottságát és az ezt befolyásoló tényezőket egy kérdőív segítségével.

A kérdőív összeállításához áttanulmányoztam a vállalati, állami digitális megfigyelésre vonatkozó szakirodalmat, és kiválasztottam azokat, amelyek alapjául szolgálnak a kérdéssorom összeállításának. ${ }^{15}$ Az összeállítás során felhasználtam 4, az Egyesült Államokban a Pew Research által 2014 és 2015 között lefolytatott online felmérés (Privacy Panels 1-4) kérdéseit is. ${ }^{16}$ A saját kérdések összeállításánál a technológiaelfogadás-modell továbbfejlesztett változata (TAM 2) alapján fogalmaztam

11 Magyarul Nemzetbiztonsági Ügynökség, az Amerikai Egyesült Államok hírszerzéssel foglalkozó egyik szervezete.

12 Bányász Péter: A közösségi média, mint a nyílt forrású információszerzés fontos területe. Nemzetbiztonsági Szemle, 3. (2015), 2. 21-36.

13 Nem kell messze menni, ha a techcégek és a kormányzatok együttműködésére szeretnénk példát találni. A Sandy-hurrikán (2012) miatt New York város Polgármesteri Hivatala együttmüködött a különböző web 2.0-s oldalakkal. A Google-lel együttműködve például interaktív krízistérképet készítettek, amelyen valós időben lehetett követni a hurrikán helyzetét, így tájékoztatva a lakosságot és segítve a katasztrófaelhárítást. Bányász Péter: A közösségi média szerepe a katasztrófaelhárításban a Sandy-hurrikán példáján keresztül. In Horváth Attila (szerk.): Fejezetek a kritikus infrastruktúra védelemböl. Budapest, Magyar Hadtudományi Társaság, 2013. 281292.

14 A megfigyelés társadalma egy olyan társadalmat jelöl, ahol a megfigyelésre használt technológiával az emberek mindennapi tevékenységét nyomon követik. Forrás: Collins English Dictionary: Surveillance Society Definition and Meaning. (é. n.).

15 Taewoo Nam: What Determines the Acceptance of Government Surveillance? Examining the Influence of Information Privacy Correlates. The Social Science Journal, 56. (2019), 4. 535.

16 Elérhetők: www.pewresearch.org/internet/datasets/. 
kérdéseket. A TAM modell lehetővé teszi, hogy megvizsgáljam egy technológiai innováció felhasználói fogadtatását, bemutatva ezzel hibáit, hiányosságait. A TAM 2 már bevonja például a szubjektív normákat is (többek között, hogy az egyén közvetlen környezete mit gondol az adott technológiáról). ${ }^{17}$ Ennél kíváncsi voltam, milyen esetekben támogatnának a kitöltők egy kínai típusú kreditrendszert.

A kérdőívben több területet is vizsgáltam. Kérdéseim kiterjedtek arra, hogy mennyire érdekli őket, vannak tudatában a felhasználók a vállalati megfigyelésnek, hogyan értékelik ezt az életükre nézve. Kíváncsi voltam, mekkora kontrollt éreznek az adataik felett egy napjuk során, hisz a kontroll érzete befolyásolja az adatvédelemmel kapcsolatos aggodalmaikat. ${ }^{18}$ Ugyanakkor nem elhanyagolható szempont, hogy mennyire találják egyszerünek a kontroll visszaszerzését, a privát böngészést. Technológiaelfogadás-modellt alkalmaztam az állami megfigyelésre koncentráló kérdéseknél, külön kitérve egy kreditrendszer elfogadhatóságára. Az összeállításnál a következő faktorokat vettem figyelembe:

- használat észlelt egyszerüsége;

- észlelt hasznosság;

- szándék;

- bizalom;

- referenciacsoport;

- ár.

A kormányzati megfigyelés elfogadhatóságánál azt is megvizsgáltam, hogy elfogadhatósága hogyan változik, ha csak különböző társadalmi csoportokra irányul. A kérdőív kitöltése online, önkéntes alapon zajlott, igyekeztem a lehető legtöbb társadalmi csoportot (különböző nemü, korcsoportú, végzettségü, politikai irányultságú stb.) megszólítani.

Az adatok kiértékelését az IBM SPSS Statistics 26 programcsomaggal, kereszttábla-elemzéssel végeztem. Segítségül használtam Sajtos László és Mitev Ariel SPSS kutatási és adatelemzési kézikönyvét is. ${ }^{19} \mathrm{~A}$ kereszttábla segítségével meg lehet állapítani, hogy két nominális vagy ordinális változó között van-e összefüggés. A Khi-négyzet $\left(\mathrm{X}^{2}\right)$ próbával kimutatható, hogy van-e a két minőségi változó között szignifikáns kapcsolat. Az SPSS program cellák megfigyelt esetszámait hasonlítja össze azzal az elvárt esetszámmal, amelyet akkor kapnánk, ha nem lenne kapcsolat a két változó között. A Khi-négyzet próba egyik alapfeltétele, hogy az elvárt gyakoriság minden cellában legalább 5 legyen, kevesebb az összes cella 20\%-ában lehet csupán. Amennyiben ez nem teljesül, eredményünket statisztikai szempontból nem lehet figyelembe venni. Ezért több esetben szükséges volt adattisztítást végeznem, hogy figyelembe vehessem a kapott értékeket. A Phi és Cramer's V asszociációs együtthatóval pedig a két nominális változó közötti kapcsolat szorosságát állapítottam meg.

17 Keszey Tamara - Zsukk János: Az új technológiák fogyasztói elfogadása. Vezetéstudomány, 48. (2017), 10. 3839.

18 Tao Zhou: Understanding Location-based Services Users' Privacy Concern: An Elaboration Likelihood Model Perspective. Internet Research, 27. (2017), 3. 506-519.

19 Sajtos László - Mitev Ariel: SPSS kutatási és adatelemzési kézikönyv. Budapest, Alinea, 2007. 
Az érték szorosságát 0 és 1 között határozza meg a program, ahol az 1 jelöli a szoros összefüggést, a 0 pedig a függetlenséget. ${ }^{20}$

A kutatási téma feldolgozása során a következö hipotéziseket állítottam fel:

H1: A magukat nyitott embernek tekintők jobban egyetértenek az online szolgáltatások hatékonyabbá válásával azáltal, hogy adatokat gyűjtenek róluk.

H2: Azon emberek szerint, akik úgy érzik, hogy digitális eszközeik a nap 24 órájában megfigyelik őket, a kormányzatnak jobban kellene szabályoznia azt, hogy a hirdetők hogyan használják fel a felhasználók adatait.

H3: Az érzékelt adatvédelmi tudatosság befolyásolja a kínai szociális pontrendszer és a különböző csoportokra irányuló, erőteljesebb állami megfigyelés megítélését.

\section{A kérdőíves felmérés eredményei}

Kérdőívemet 276 -an töltötték ki $(n=276)$, amelyböl $68,8 \%$ nő volt. A legtöbb kitöltés a 18-25 évig terjedő korcsoportból volt (55,4\%), a legkevesebb a 65 év felettiekéböl $(n=4)$.

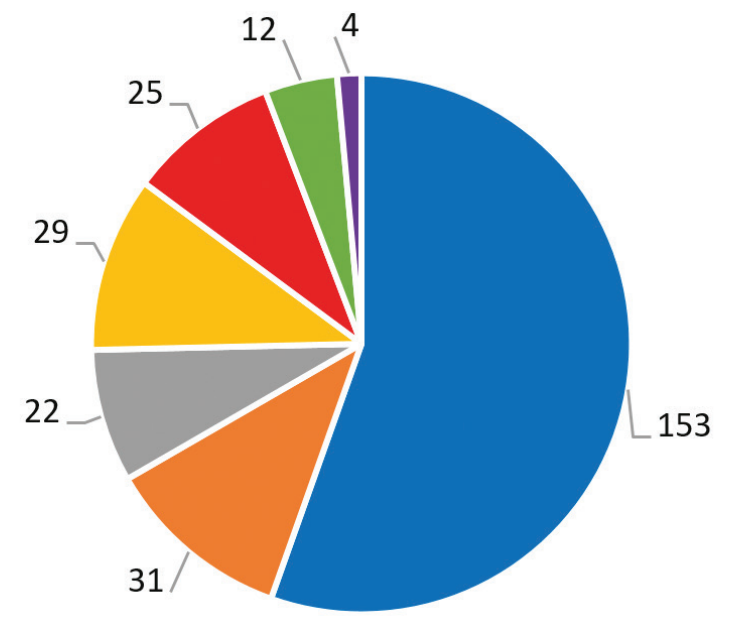

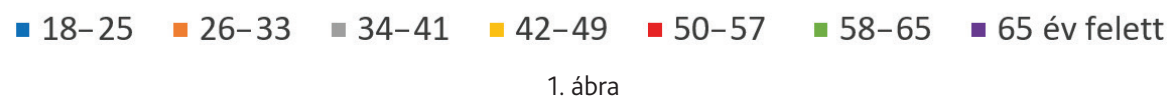

A kérdöívet kitöltök megoszlása korcsoport szerint

Forrás: a szerző szerkesztése

A politikai világnézetre vonatkozó kérdésnél megoszlottak a válaszok, 39,5\%-uk nem tudta/nem kívánta megválaszolni a kérdést. Ugyanakkor 25,7\%-uk liberálisnak,

20 SPSS ABC: Khi négyzet próba jelentése és alkalmazása az SPSS-ben. (é. n.). 
19,9\%-uk konzervatívnak, 12\% pedig centralistának vallotta magát. A magukat baloldalinak vallók száma csupán $8(n=8)$. Fontos kiemelni, hogy a politikai világnézetre irányuló kérdés önbevalláson alapszik, tehát előfordulhat, hogy az egyén magáénak tartott irányultsága nem egyezik a szakirodalmakban tárgyaltakkal.

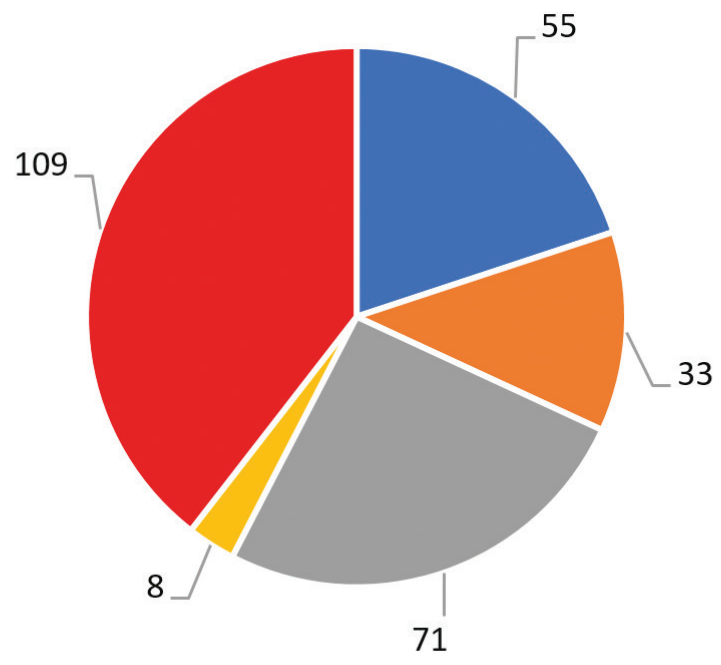

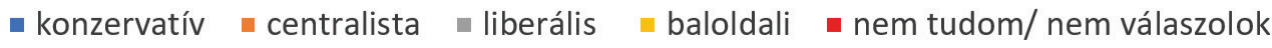
2. ábra

A kérdőívet kitöltők megoszlása politikai világnézet szerint Forrás: a szerző szerkesztése

A válaszadók $55,8 \%$-a ( $n=154)$ magát nyitott embernek gondolja, a többiek inkább privát szférájukra érzékenyként definiálták önmagukat. A közösségimédia- és internethasználat felmérésénél (adattisztítást követően) világossá vált, hogy a kitöltők többsége napjában többször: 1. használja okostelefonját ( $n=266) ; 2$. használ valamilyen keresőmotort, például Google-t vagy Binget $(n=257) ; 3$. látogat közösségi oldalakat, például Facebookot, Instagramot $(n=245)$.

A válaszadók önértékelését, tehát, hogy nyitottnak vagy privát szférájukra érzékeny embernek tartják-e magukat, összevetettem a tartózkodási helymeghatározás engedélyezésének gyakoriságával (lásd 3. ábra). A válaszadók 44,9\%-a úgy nyilatkozott, hogy nagyon ritkán, 26,4\%-uk néha, 19,2\%-uk soha, 9,4\%-uk pedig gyakran osztja meg tartózkodását. A Khi-négyzet teszt $\left(X^{2}=13,471 ; \mathrm{df}=3\right)$ kétoldali szignifikanciaszintje 0,004 , tehát kapcsolat állapítható meg a két változó között. A Cramer's V mutató megfigyelt értéke 0,221, tehát nem túl erős, moderált kapcsolatot állapíthatunk meg a között, hogy valaki mennyire vallja nyitottnak magát és milyen gyakran engedélyezi a tartózkodási helyének megosztását. 


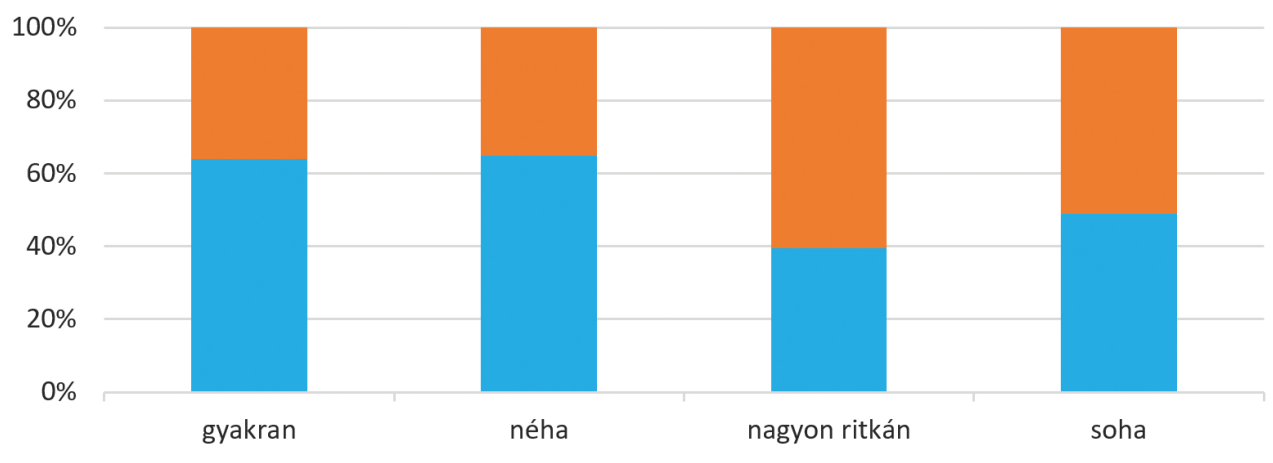

Amikor különböző applikációkat használ, és a telefonja vagy a tabletje engedélyt kér a tartózkodási helyének a meghatározásához, milyen gyakran engedélyezi?

घ nyitott ember vagyok घ privát szférájára érzékeny ember vagyok

3. ábra

A privát szférára való érzékenység és a tartózkodási hely megosztására való hajlandóság közti összefüggés

Forrás: a szerző szerkesztése

Kíváncsi voltam arra, hogy a kitöltők mekkora kontrollt érzékelnek a róluk gyüjtött adatok felett, amikor interneten böngésznek, okostelefont használnak. A 4. ábrán látható, hogy a válaszadók 44,2\%-a $(n=122)$ szerint nincs túl sok kontrollja a róla gyüjtött adatok és azok felhasználása felett. Azonban 39,9\%-uk $(n=110)$ úgy véli, valamilyen szinten az irányítása alatt vannak a róla gyüjtött információk.

\section{Végiggondolva a napját, hogy érzi, mekkora irányítása van az Önről gyűjtött információk és annak felhasználási módja felett?}

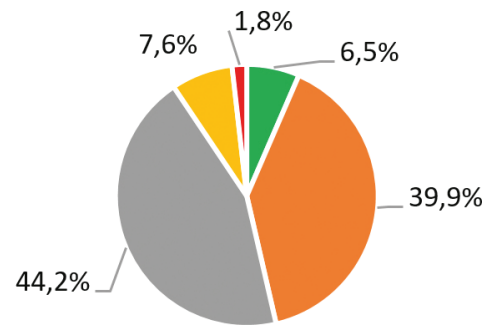

\footnotetext{
- teljes mértékben irányításom alatt van * valamilyen szinten irányításom alatt van

- nincs túl sok kontrollom felette - nincs kontrollom felette

- nem tudom/ nem nyilatkozom
}

\section{4. ábra}

Az adatok feletti kontroll érzékelése

Forrás: a szerző szerkesztése 
Így megállapítható, hogy nincs túl nagy eltérés a nem sok kontrollt és a valamilyen szintű irányítást érzékelök mennyisége között. Csupán 6,5\% gondolta úgy, hogy teljes mértékben az irányítása alatt állnak az információk. További Khi-négyzet próbának vetettem alá, hogy vajon a privát szférára való érzékenység és annak a megítélése, hogy az online szolgáltatások a felhasználókról gyűjtött adatok miatt egyre hatékonyabbak között van-e kapcsolat.

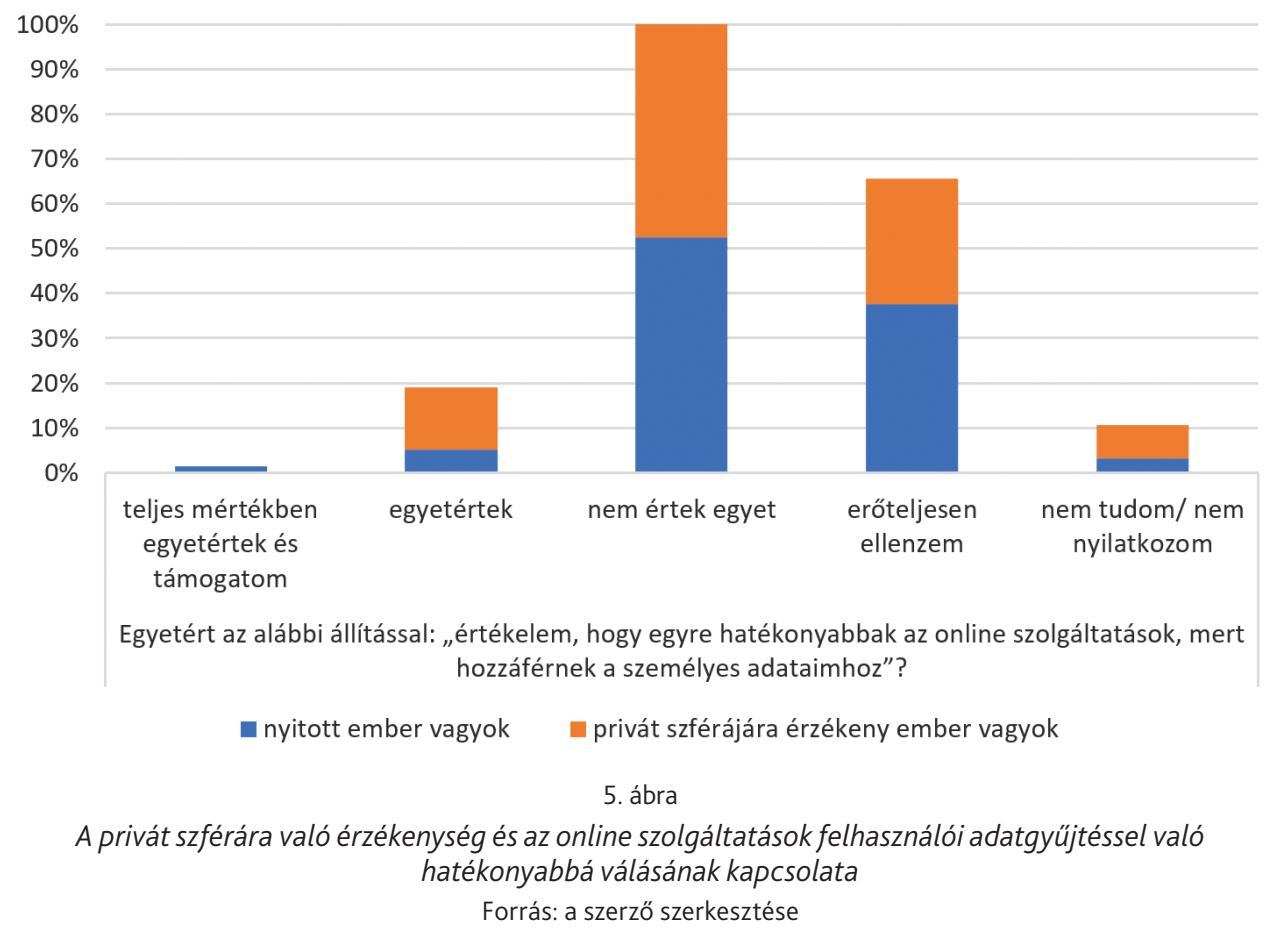

A Khi-négyzet megfigyelt értéke $11,624(\mathrm{df}=4)$, a kétoldali szignifikanciaszint pedig 0,02 , vagyis jelentős kapcsolat áll fenn. A Cramer's V mutató értéke 0,205 , tehát egy nem túl erős kapcsolatról beszélhetünk. Tehát az, hogy valaki érzékeny-e a privát szférájára, befolyásolja az online szolgáltatások adataink általi hatékonyabbá válásának megítélését.

Megvizsgáltam, hogy az emberek tartanak-e attól, hogy digitális eszközeik a nap 24 órájában megfigyelik őket. 52,2\% igennel, 26,1\% pedig nemmel válaszolt, 21,7\%-ukat nem érdekelte. Az ezekkel kapcsolatos érzéseket összevetettem azzal, hogy szerintük jobban kellene-e a kormányzatnak szabályozni azt, hogy a felhasználókról gyüjtött adatokat hogyan használják fel a hirdetők. Itt a válaszadók jelentős többsége, 85,9\%-a gondolta úgy, hogy nagyobb szabályozásra szorul e terület. A vizsgálat Khi-négyzet megfigyelt értéke 10,212 ( $d f=2)$, kétoldali szignifikanciaszintjének értéke $p=0,006$, tehát megállapítható, hogy a két változó közötti kapcsolat szignifikáns. A Cramer's 
V mutató értéke 0,192, tehát egy laza, gyenge kapcsolatról beszélünk. Az eredményt a 6. ábrán ábrázoltam.

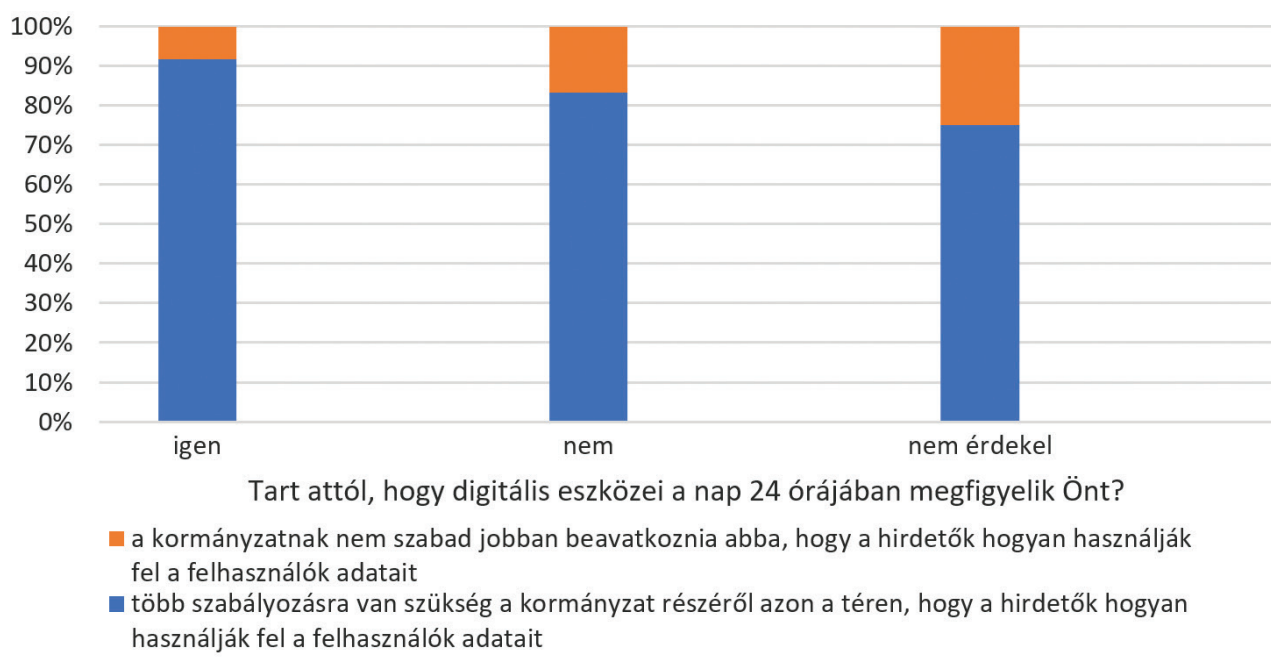

$$
\text { 6. ábra }
$$

A digitális megfigyeléstöl való félelem és a kormánytól elvárt magatartás a hirdetök adatfelhasználásával kapcsolatos összefüggése

Forrás: a szerző szerkesztése

A kérdőív harmadik részében a digitális állami megfigyelés több aspektusáról is megkérdeztem a válaszadókat. A 7. ábrán látható, mennyire érdekelné a digitális állami megfigyelés a kitöltőket.

\section{Mennyire törődne azzal, ha a kormányzat felügyelné a digitális készülékein történő kommunikációját és adatforgalmát?}

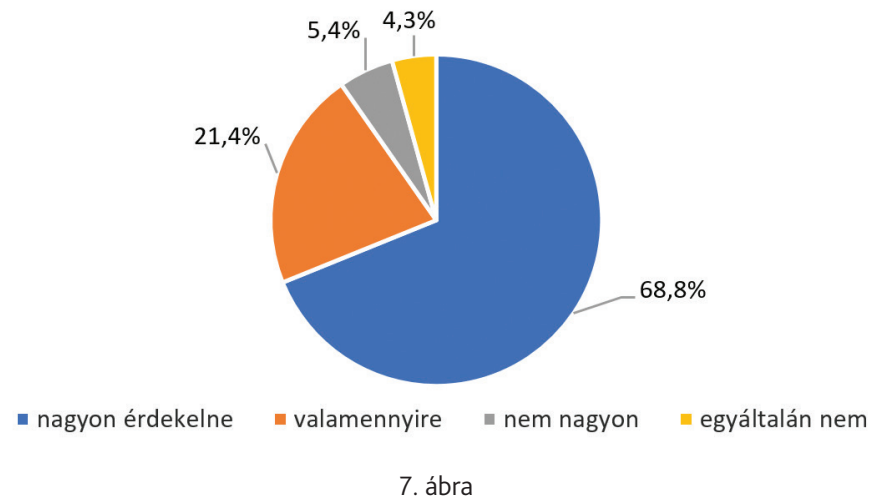

Az esetleges digitális állami megfigyeléssel szemben tanúsított érdeklödés a kitöltők szerint Forrás: a szerző szerkesztése 
Látható, hogy 68,8\%-ot nagyon is érdekelné, ha felügyelnék őt az állami szervek, amit a valamennyire érdeklődők követnek. Csupán 4,3\%-uk vélekedett úgy, hogy egyáltalán nem foglalkozna ezzel. A következő ábrán a bűnmegelőzés, bűnüldözés elősegitése érdekében történő megfigyelés támogatottsága látható.

Egyetért azzal, hogy a kormányzat adatokat gyújtsön Önról (pl. közösségi oldalak használati szokásai, telefonhívásai, térfigyelő kamerák) a hatékony bűnmegelőzés és bűnüldözés elősegítése érdekében?

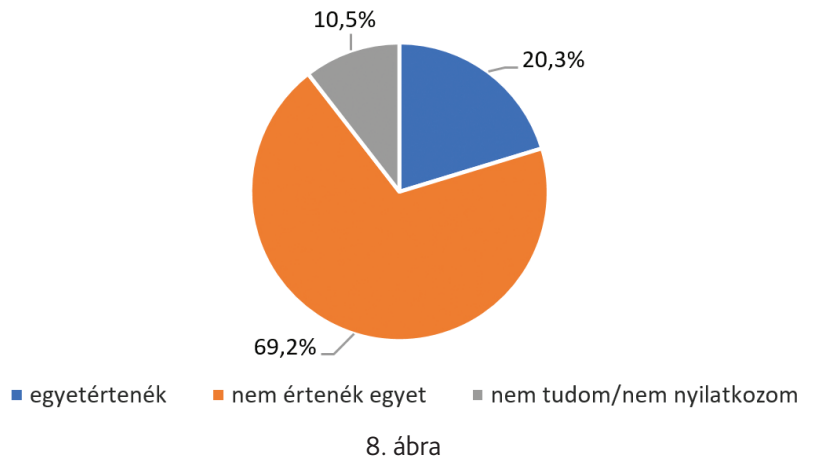

A digitális állami megfigyelés elfogadhatósága a bünüldözés, bünmegelőzés elösegitése esetén Forrás: a szerző szerkesztése

A kitöltők többsége, 69,2\% nem értene egyet akkor sem a digitális állami megfigyeléssel, ha az a bủncselekmények elleni védekezést, megelőzést segítené elő. 20,3\%-uk pedig egyetértene vele.

Megvizsgáltam, hogy a kitöltők mennyire éreznék hasznosnak, ha az emberek azt hinnék, valaki folyamatosan figyeli az online tevékenységüket.

\section{Hasznos lenne a társadalomnak, ha az emberek azt hinnék,} valaki folyamatosan felügyeli az online tevékenységüket?

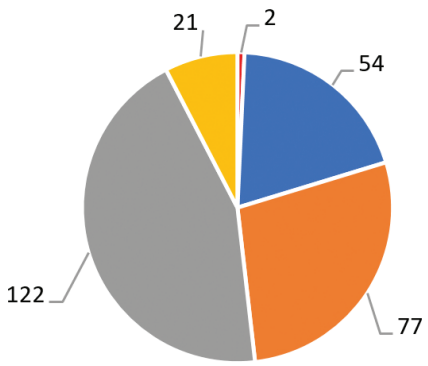

- erőteljesen egyetértek

- nem értek egyet
- egyetértek

- nem tudom/ nem nyilatkozom

9. ábra

Az online tevékenység folyamatos figyelésébe vetett hit vélt társadalmi hasznossága

Forrás: a szerző szerkesztése 
A kitöltők 44,2\%-a nem értett egyet, 77-en pedig határozottan nem értettek egyet. 19,6\% viszont egyetértett, csupán 2 személy támogatta erőteljesen.

A 26. kérdésben röviden felvázoltam a kínai szociális kreditrendszer jellemzőit, és kértem a kitöltőket, hogy egy 1-től 5-ig terjedő Likert-skálán fejezzék ki véleményüket (az 1 a határozottan nem értek egyet, az 5 pedig a határozottan egyetértek) bizonyos szempontok alapján. A válaszok nagy része ellenezte az ilyen típusú rendszer bevezetését, azonban kíváncsi voltam, a vélt adatvédelmi tudatosság mennyire befolyásolja az egyes kérdésekre adott választ. Megnéztem továbbá, hogy aszerint, hogy a feltételezett online tevékenység megfigyelésének társadalmi hasznosságát hogyan ítélték meg, van-e különbség a csoportok között, ha a digitális állami megfigyelésről beszélünk.

Ennek érdekében lefuttattam a Kruskal-Wallis-tesztet. A K-W-teszt egy nonparaméteres megfelelője az egyszempontos varianciaanalízisnek (ANOVA), amely megmutatja, hogy van-e vagy nincs statisztikailag szignifikáns különbség három vagy több különbözö, független csoport középértéke között. ${ }^{21}$

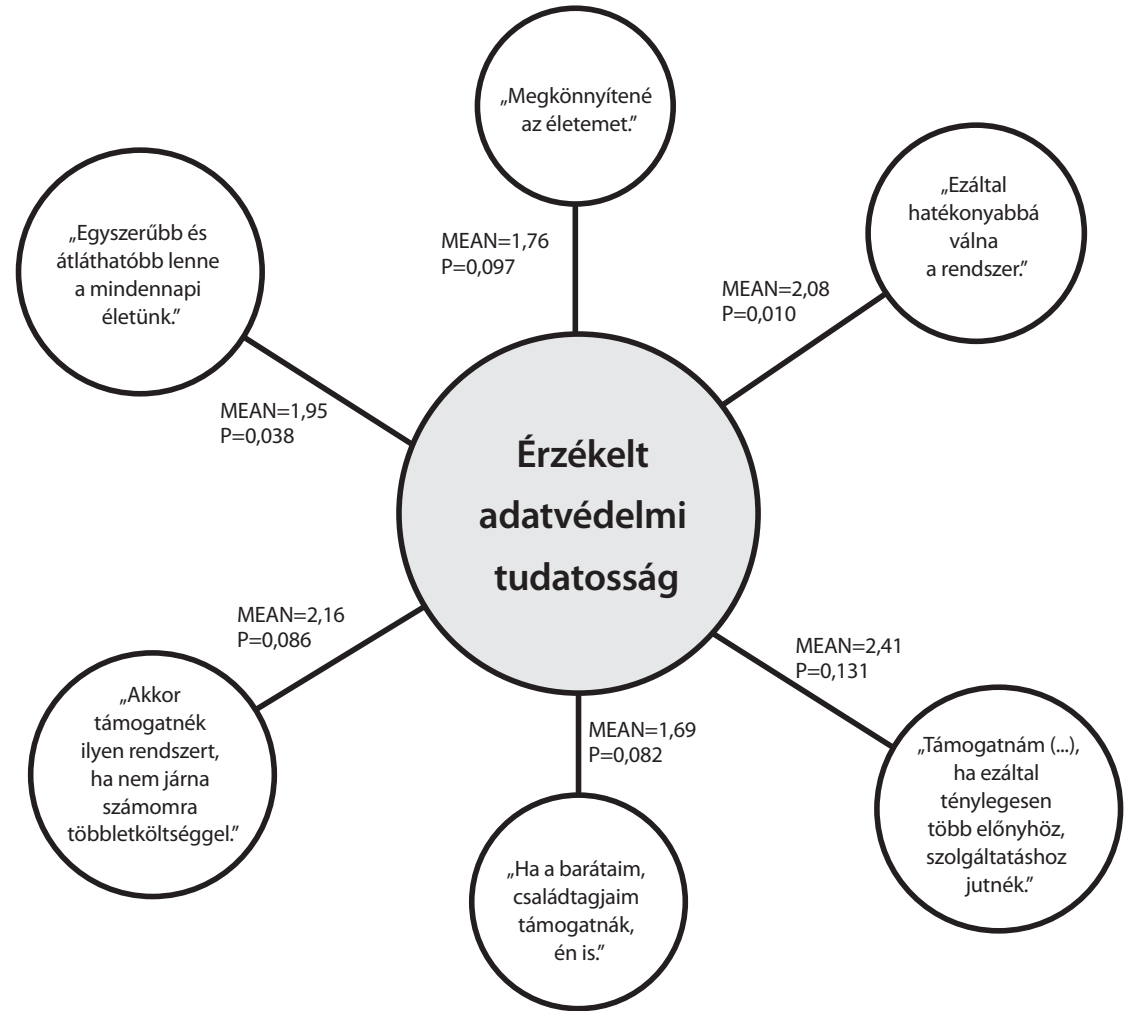

10. ábra

Az érzékelt adatvédelmi tudatosság hatása a kínai szociális rendszer megitélésére

Forrás: a szerző szerkesztése

21 Kruskal-Wallis Test: Definition, Formula, and Example. Statology (blog), 2019. január 18. 
A középértékek 1,69 és 2,41 között változtak, tehát a "határozottan nem értek egyet” és a „nem értek egyet” között. Szignifikáns különbség mutatkozik meg a vélt adatvédelmi tudatosság alapján besorolt csoportok között két esetben. Az egyszerübb, átláthatóbb életre vonatkozó állításnál és a hatékonyságra vonatkozó kérdésnél a szignifikanciaszint 0,05 alatt van, tehát a nullhipotézist elvethetjük. Ezekben az esetekben a legmagasabb rangátlaga a magukat nem adatvédelmileg tudatosnak vallóknak van, tehát sorban náluk a legmagasabb az egyetértésre való hajlam. A legalacsonyabb rangátlaga pedig a magukat tudatosnak vallóknak van. Nem tapasztalható azonban különbség a csoportok között a többi állításra vonatkozó kérdés esetén.

A 27. kérdésben arra voltam kíváncsi, hogy az állami megfigyelést mennyire tartják a kitöltők elfogadhatónak, ha különböző csoportokra irányulna, úgymint állampolgárok, büncselekménnyel összefüggésbe hozható személyek, állami vezetők, külföldiek (bevándorlók). Ennél a kérdésnél rákérdeztem egy egységes állami, személyhez köthető adatbázis támogatottságára is. Ezt összevetettem a vélt adatvédelmi tudatossággal.

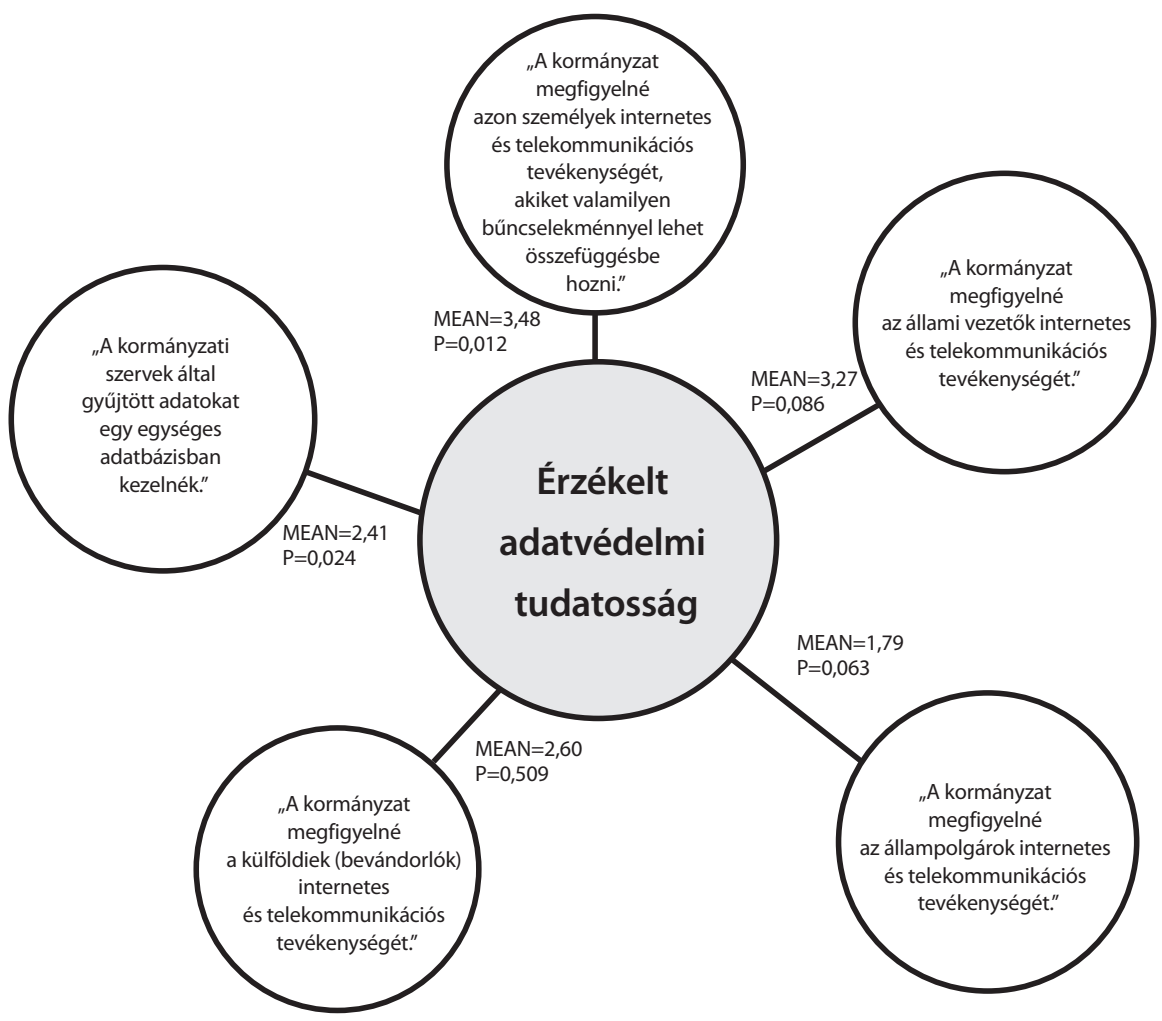

11. ábra

Az érzékelt adatvédelmi tudatosság hatása a digitális állami megfigyelésre, bizonyos csoportokra való irányulás esetén

Forrás: a szerző szerkesztése 
Itt már a középértékek többnek bizonyultak bizonyos esetekben az előző kérdéshez képest. Viszonylag magas a középérték a büncselekménnyel összefüggésbe hozható személyek digitális állami megfigyelésére adott válaszok esetén. Ugyanígy az állami vezetőkre és bevándorlókra irányuló megfigyelés esetén. Szignifikáns különbség tapasztalható a csoportok között abban az esetben, ha a büncselekménnyel összefüggésbe hozható személyek megfigyeléséről van szó, illetve a kormányzati szervek által létrehozott egységes adatbázis esetén. A legmagasabb rangátlaga szintén a magukat nem tudatosnak vallóknak van, a legalacsonyabb pedig a magukat tudatosnak vallóknak.

Megvizsgáltam, hogy a „Hasznos lenne a társadalomnak, ha az emberek azt hinnék, valaki folyamatosan felügyeli az online tevékenységüket?" kérdésre adott válaszok csoportjai között van-e szignifikáns különbség, ha a kínai típusú szociális kreditrendszer megítéléséról van szó. Adattisztítást végeztem annak érdekében, hogy megfelelően tudjam vizsgálni az adott csoportokat. Így az „erőteljesen egyetértek" és „egyetértek" választ adók csoportját összevontam.

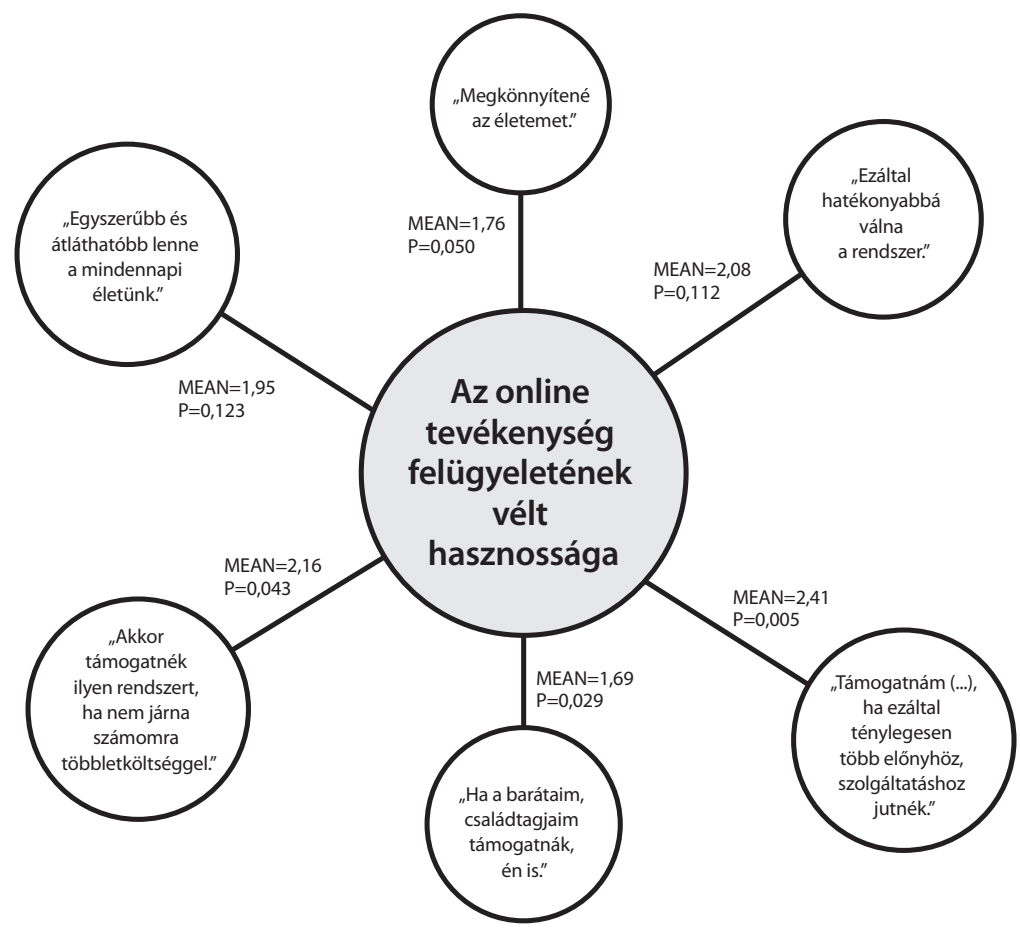

12. ábra

A online tevékenység megfigyelésének társadalmi hasznosságával való egyetértés hatása a kínai szociális rendszer megitélésére

Forrás: a szerző szerkesztése

Különbség tapasztalható a csoportok között három esetben is. Amennyiben a kreditrendszer nem járna többletköltséggel, több előnnyel és szolgáltatással járna és a barátok, 
családtagok is támogatnák a kiépülését, szignifikáns az eltérés a válaszadók között. A legalacsonyabb rangátlaga a „határozottan nem értek egyet” választ adók csoportjának van, tehát sorban náluk a legnagyobb az elutasításra való hajlam. A legmagasabb rangátlaga pedig az „erőteljesen egyetértek/egyetértek” csoportnak van.

Megvizsgáltam a csoportokat a 27. kérdésre adott válaszok esetén is. Eredményemet a következő ábrán szemléltettem.

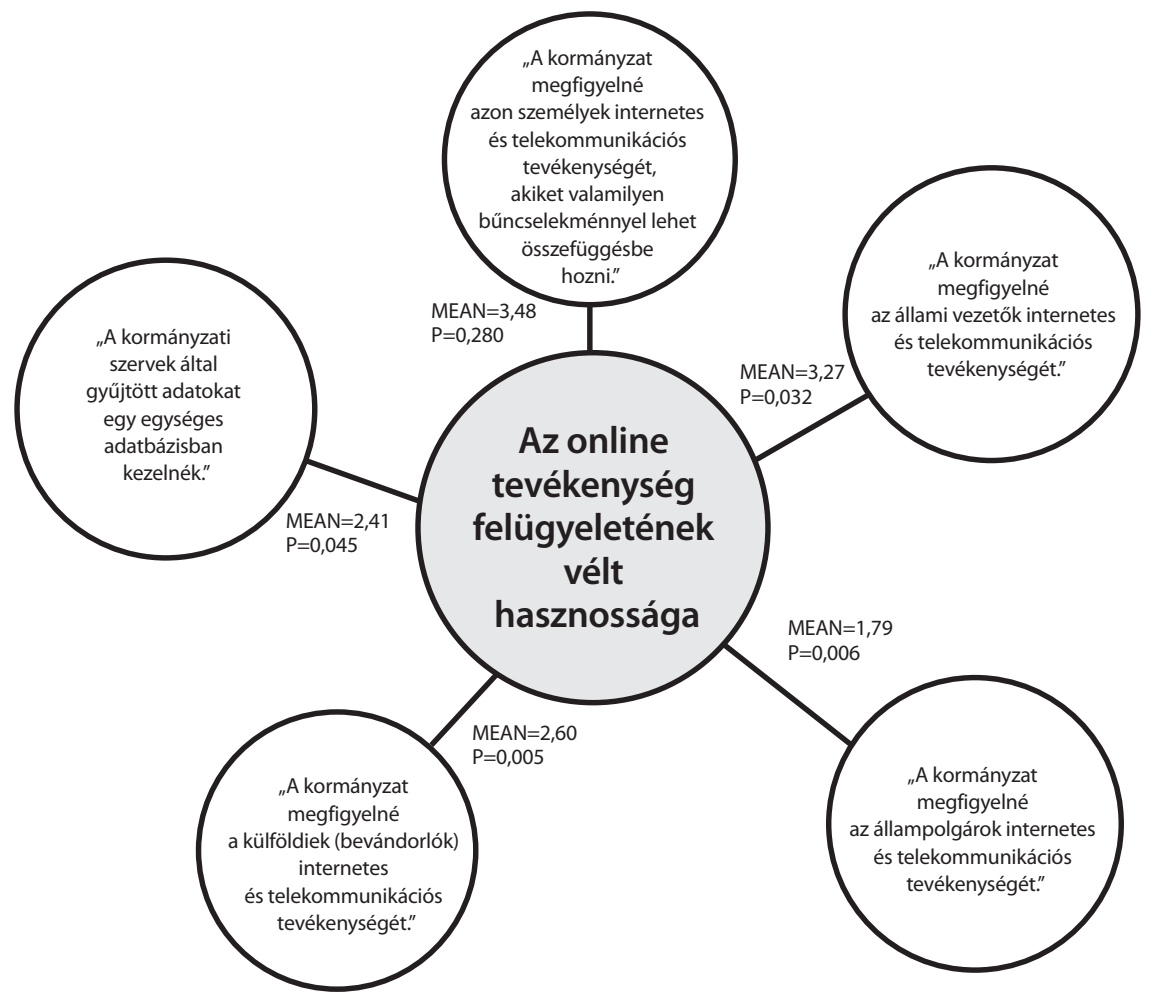

13. ábra

A online tevékenység megfigyelésének társadalmi hasznosságával való egyetértés hatása a digitális állami megfigyelésre, bizonyos csoportokra való irányulás esetén

Forrás: a szerző szerkesztése

Majdnem minden válasz esetén tapasztalható a különbség a csoportok között, csak a bűncselekménnyel összefüggésbe hozható személyek esetén áll fenn a nullhipotézis esete. Sorban azoknak a legmagasabb a rangátlaga, akik szerint hasznos lenne a társadalomnak, ha az emberek azt hinnék, valaki megfigyeli öket, legalacsonyabb pedig azoknak, akik ezt ellenzik. 


\section{Következtetések}

A kutatási téma feldolgozása során a következő eredményeket kaptam:

T1: A privát szférára való érzékenység befolyásolja az online szolgáltatások adatgyüjtésük általi hatékonyabbá válásának megítélését, a magukat nyitottabbnak vallók egyetértőbbnek bizonyultak.

T2: Azon emberek szerint, akik úgy érzik, hogy digitális eszközeik a nap 24 órájában megfigyelik őket, a kormányzatnak jobban kellene szabályozni azt, hogy a hirdetők hogyan használják fel a felhasználók adatait.

T3: Az érzékelt adatvédelmi tudatosság befolyásolja a kínai szociális pontrendszer egyes aspektusainak és az egyes csoportokra irányuló, erőteljesebb állami megfigyelés megítélését.

A kérdőíves felmérésből megállapíthatom, hogy a válaszadók kicsivel több mint fele magát nyitott emberként definiálja. Nagy részük, 59,4\%-uk pedig többé-kevésbé adatvédelmileg tudatosnak gondolja önmagát. Azonban a Facebook alkalmazáshoz szükséges engedélyek számának eltévesztése kimagasló volt az adatvédelmileg tudatos, nem tudatos és többé-kevésbé tudatosok körében is, nincs összefüggés az érzékelt tudatosság és a tudás között e tekintetben. Megállapíthatom továbbá, hogy a privát szférára való érzékenység befolyásolja a tartózkodási hely megosztására való hajlandóságot. Minél nyitottabb valaki, annál valószínűbb, hogy megosztja ezen adatait. A mesterséges intelligencia prognosztikus képességét igaznak vagy többé-kevésbé igaznak ítélték meg az emberek, megítélésük és privát szférára való hajlandóságuk között nincs szignifikáns kapcsolat.

Az emberek többsége úgy érzi, hogy nincs túl sok kontrollja a róla gyüjtött adatokról, és tart attól, hogy digitális eszközei a nap 24 órájában megfigyelik őt. Ez a félelem összefüggésben áll azzal, hogy szerintük a kormánynak több intézkedést kell tenni azon a téren, hogy a hirdetők hogyan használják fel a felhasználók adatait. Érdekes, hogy míg a nagy techcégek a megfigyelés pozitívumaként hozzák fel a személyre szabottabb tartalmat, a kérdőívből inkább az látszik, hogy az emberek nem értékelik annak, főleg, ha az adataik átadása a magánszféra szükülésével jár. A kreditrendszerre és állami megfigyelésre vonatkozó kérdésnél láthattuk, hogy az emberek többségében nem támogatják, azonban vannak olyan szempontok (nem jár többletköltséggel, több szolgáltatáshoz való hozzáférés), amelyek vonzóbbá tehetik. A kínai szociális kreditrendszer gyakorlatában a büncselekménnyel összefüggésbe hozható személyek internetes és telekommunikációját tartják a leginkább elfogadhatónak. Szignifikáns különbség tapasztalható a csoportok között abban az esetben, ha a büncselekménnyel összefüggésbe hozható személyek megfigyelését feltételezem, illetve, ha a kormányzati szervek által gyüjtött adatok egységes adatbázisban történő kezeléséről van szó. 


\section{Felhasznált irodalom}

Bányász Péter: A közösségi média szerepe a katasztrófaelhárításban a Sandy-hurrikán példáján keresztül. In Horváth Attila (szerk.): Fejezetek a kritikus infrastruktúra védelemböl. Budapest, Magyar Hadtudományi Társaság, 2013. 281-292. Online: http://real.mtak.hu/94342/1/A_kozossegi_media_szerepe_a_katasztrofae.pdf

Bányász Péter: A közösségi média szerepe a lélektani műveletekben az elmúlt időszak válságainak tükrében. Szakmai Szemle, 13. (2016), 1. 61-81. Online: http://real. mtak.hu/47801/1/A_kozossegi_media_szerepe_a_lelektani_mu.pdf

Bányász Péter: A közösségi média, mint a nyílt forrású információszerzés fontos területe. Nemzetbiztonsági Szemle, 3. (2015), 2. 21-36. Online: http://real.mtak. hu/72506/1/nbszemle_20152_banyasz.original_u.pdf

Collins English Dictionary: Surveillance Society Definition and Meaning. (é. n.). Online: www.collinsdictionary.com/dictionary/english/surveillance-society

Gan, Nectar: China is Installing Surveillance Cameras Outside People's Front Doors ... And Sometimes Inside Their Homes. CNN Business, 2020. április 28. Online: https://edition.cnn.com/2020/04/27/asia/cctv-cameras-china-hnk-int//index.html

Genia Kostka - Lukas Antonie: China's social credit systems and public opinion: Explaining high levels of approval. New MediaESociety, 21. (2019), 7. 1565-1593. Online: https://doi.org/10.1177/1461444819826402

Herczeg Márk: Eljött az idő, amikor az online tevékenységed alapján pontozzák, menynyire vagy megbízható állampolgár. 444, 2020. január 27. Online: https://444. hu/2020/01/27/eljott-az-ido-amikor-az-online-tevekenyseged-alapjan-pontozzak-mennyire-vagy-megbizhato-allampolgar

Joe Resendiz: Average Credit Score in America: 2021 Report. Valuepenguin, 2021. július 9. Online: www.valuepenguin.com/average-credit-score

Johnson, Craig: The truth about how Facebook can affect your credit score. Clark, 2017. december 11. Online: https://clark.com/personal-finance-credit/social-meadia-facebook-credit-scores/

Kaplan, Andreas - Michael Haenlein: Siri, Siri, in My Hand: Who's the Fairest in the Land? On the Interpretations, Illustrations, and Implications of Artificial Intelligence. Business Horizons, 62. (2019), 1. 15-25. Online: https://doi.org/10.1016/j. bushor.2018.08.004

Keszey Tamara-Zsukk János: Azúj technológiák fogyasztói elfogadása. Vezetéstudomány, 48. (2017), 10. 38-47. Online: https://doi.org/10.14267/VEZTUD.2017.10.05

Kruskal-Wallis Test: Definition, Formula, and Example. Statology (blog), 2019. január 18. Online: www.statology.org/kruskal-wallis-test/

Mihálydeák Tamás: A mesterséges intelligencia alapjai. Előadás. 2018. február 3. Online: https://arato.inf.unideb.hu/mihalydeak.tamas/Mest_int_2017_18_2_print.pdf

Pew Research: Privacy Panels 1-4. Elérhetőek: www.pewresearch.org/internet/datasets/ Letöltés dátuma: 2020. szeptember 10.

Sajtos László - Mitev Ariel: SPSS kutatási és adatelemzési kézikönyv. Budapest, Alinea, 2007.

Shoshana Zuboff: The Age of Surveillance Capitalism. London, Profile Books Ltd, 2019. 
SPSS ABC: Khi négyzet próba jelentése és alkalmazása az SPSS-ben. (é. n.). Online: https://spssabc.hu/ketvaltozos-elemzes/khi-negyzet-proba/

Taewoo Nam: What Determines the Acceptance of Government Surveillance? Examining the Influence of Information Privacy Correlates. The Social Science Journal, 56. (2019), 4. 530-544. Online: https://doi.org/10.1016/j.soscij.2018.10.001

Zhou, Tao: Understanding Location-based Services Users' Privacy Concern: An Elaboration Likelihood Model Perspective. Internet Research, 27. (2017), 3. 506-519. Online: https://doi.org/10.1108/IntR-04-2016-0088

Zuboff, Shoshana: The Age of Surveillance Capitalism. London, Profile Books Ltd., 2019. 